\title{
An interrupting mechanism to prevent the formation of coastal hypoxia by winds
}

\author{
Juan Yao ${ }^{1,2}$, Juying Wang ${ }^{3}$, Hongbin Liu ${ }^{2,4}$, Kedong Yin ${ }^{1,2 *}$
}

3

$4{ }^{1}$ School of Marine Sciences/Guangdong Key Laboratory of Marine Resources and Coastal

5 Engineering, Sun Yat-Sen University, Guangzhou 510275, Guangdong, China.

$6 \quad{ }^{2}$ Southern Marine Science and Engineering Guangdong Laboratory (Zhuhai), Zhuhai 519082 ,

7 Guangdong, China.

$8 \quad{ }^{3}$ National Marine Environmental Monitoring Center, Ministry of Ecology and Environment,

9 Dalian 116023, Liaoning, China.

$10{ }^{4}$ Department of Ocean Sciences, Hong Kong University of Science and Technology, Clear Water

11 Bay, Hong Kong SAR, China.

12

Corresponding author: Kedong Yin (yinkd@ mail.sysu.edu.cn)

Email address for each author listed: Juan Yao (yaoj8@mail2.sysu.edu.cn); Juying Wang

(jywang@nmemc.org.cn); Hongbin Liu (liuhb@ust.hk)

17 Running head: frequent winds interrupt the formation of hypoxia

18 Keywords: hypoxia; wind events; Hong Kong waters; ecosystem buffering; climate change 


\section{Abstract}

Enrichment of nutrients is believed to lead to coastal hypoxia which have become a seasonal phenomenon over large river estuarine areas such as the Mississippi River-Northern Gulf of Mexico and Changjiang-East China Sea. There is a similar nutrient enrichment process in the Pearl River. However, hypoxia occurs only as episodic events over a relatively small area. We hypothesize that frequent wind events play the interruptive mechanism in preventing the seasonal formation of bottom hypoxia. We used 29 years time series data of dissolved oxygen (DO) and winds in the Hong Kong coastal waters to test the hypothesis. Our results show that bottom DO at 3 stations in southern waters of Hong Kong occasionally drops below the hypoxic level ( $2 \mathrm{mg} / \mathrm{L})$, lasting only for less than one month in summer. Episodic hypoxia events appear to occur more frequently in recent years, but bottom DO does not show a significantly decreasing trend. The wind speed of $6 \mathrm{~m} / \mathrm{s}$ appears to be a threshold, above which a wind event could destroy water column stratification and interrupt the formation of low-oxygen (DO $<3 \mathrm{mg} / \mathrm{L}$ ) water mass. The wind events above the threshold occur 14.3 times in June, 14.2 times in July and 10.0 times in August during 1990-2018. This explains why episodic events of hypoxia hardly occur in June and July, and only occasionally in August. The frequency of such the abovethreshold events appears to show a decreasing trend during 1990-2018, which coincides with an increasing occurrences of episodic hypoxia events in recent years.

\section{Introduction}

Hypoxic environments are natural existence throughout geological time and distributed in many coastal ecosystems around the world (Diaz and Rosenberg 2008). During the past halfcentury, however, the duration, intensity and extent of coastal hypoxia have been exacerbated by the increased nutrients input associated with human activities (Breitburg et al. 2018; Du et al. 
2018). Typical examples of large dead zones in coastal zones around the world include Baltic Sea, northern Gulf of Mexico, northwestern shelf of the Black Sea and Changjiang-East China Sea (Bianchi et al. 2010; Capet et al. 2013; Vali et al. 2013; Zhu et al. 2016).

The Pearl River is the second largest river in China and the $13^{\text {th }}$ largest in the world. The annual average river discharge is $10,524 \mathrm{~m}^{3} \mathrm{~s}^{-1}$ with $20 \%$ occurring during the dry season and $80 \%$ during the wet season (Yin et al. 2004). The Pearl River estuary flows into the northern part of the South China Sea. Hong Kong is part of its eastern shores (Figure 1). The Pearl River estuarine coastal waters are very dynamic driven by factors such as river discharge, oceanic waters, coastal currents and monsoons (Yin et al. 2004).

In recent years, the loading of anthropogenic nutrients has been increasing in the Pearl River (Hu and Li 2009; Su et al. 2017), which is comparable to Mississippi and Yangtze where hypoxia has become a seasonal phenomenon ( $\mathrm{Li}$ et al. 2002; Rabalais et al. 1998, 2002, 2010; Zhu et al. 2011; Wang et al. 2016). The increase in nutrients in the coastal waters is usually assumed to result in hypoxia in the estuary and coastal waters. However, over the coastal scale of the Pearl River estuarine influenced waters in the South China Sea, hypoxia has only occurred as episodic events over small areas (Yin et al. 2004; Xu et al. 2010; Li et al. 2019). Recent investigations reported a new occurrence of hypoxia in the coastal waters south of Macau (Ye et al. 2013; Su et al. 2017; Lu et al. 2018; Qian et al. 2018), but the spatial scale is only a small part of the Pearl River estuarine plume which influences the large part of the Northern South China Sea.

Water column stratification and decomposition/oxygen consumption of organic matter in the bottom water are two critical factors that lead to hypoxia, and both favourable conditions must occur simultaneously for hypoxia to develop and persist (Diaz 2001). An event of episodic 
hypoxia in the Pearl River coastal waters was related to the hydrodynamics and water depth (Zhou et al. 2012; Ye et al. 2013; Qian et al. 2018). In addition to the buoyancy flux induced by freshwater discharge, local wind forcing plays a regulating role in the stratification stability. Previous studies found that wind-driven vertical mixing accelerates the ventilation of water column and increases oxygen replenishment in the bottom layer in the Pearl River estuarine coastal waters (Zhou et al. 2012; Wang et al. 2015) and other regions (Wilson et al. 2008; Scully 2010, 2013). For example, bottom DO in hypoxic zone was observed to increase rapidly after the passage of a typhoon ( $\mathrm{Ni}$ et al. 2016; Su et al. 2017). However, the mixing effect of typhoons is relatively short-lived in coastal ecosystems and the enhanced freshwater discharge can reestablish stratification in only a few days (Zhou et al. 2012), which facilitates the re-formation of hypoxia (Su et al. 2017). Therefore, whether strong wind events relieve the tendency of hypoxia on a longer time scale depends partly on the frequency of wind events. Numerical modeling studies have illustrated the effects of wind stress/speed variations on coastal hypoxia (Chen et al. 2015; Wei et al. 2016; Lu et al. 2018). However, the role of frequency of wind events on the formation and maintenance of hypoxia is rarely studied, partly due to lack of long time series data. In order to explain the lack of seasonal phenomenon of hypoxia over the coastal scale in the Pearl River estuarine waters, we hypothesize that frequent wind events interrupt the formation of bottom hypoxia and prevent hypoxia from becoming a persistent seasonal phenomenon in the Pearl River estuarine coast. We used 29 years (1990-2018) time series data of dissolved oxygen and winds in Hong Kong to test the hypothesis. The approach is to examine the temporal trend of dissolved oxygen and frequency of wind speeds and to determine a threshold of wind speeds above which a wind event is strong enough to interrupt the formation of hypoxia. 


\section{Materials and Methods}

The time series data of DO and other water quality variables at three stations SM17, SM18 and SM19 during 1990-2018 are obtained from the Environmental Protection Department (EPD) which has maintained a comprehensive marine water quality monitoring programm since 1986 at 86 stations (Figure 1). The marine monitoring vessel "Dr. Catherine Lam" is equipped with a CTD profiler and a computer-controlled rosette water sampler to measure salinity, temperature and dissolved oxygen in situ and collect water samples for nutrients for later analysis in the laboratory. The water samples were analyzed in the EPD's laboratory (EPD Report 2017). The three stations SM17, SM18 and SM19 are located in the southern waters of Hong Kong in coastal area of the Northern South China Sea, with depths being 12 m, $21 \mathrm{~m}$ and $24 \mathrm{~m}$, respectively (Figure 1). They are visited monthly for sampling. They are heavily influenced by the Pearl River estuarine plume during summer. Station SM18 is located in the southern end of Lamma Channel, the north end of which receives the sewage effluents from the outfalls of the CEPT (Chemically Enhanced Primary Treatment) of Stonecutter's Island Works.

The daily averaged wind speeds and prevailing wind directions at Waglan Island $(\mathrm{N}$ $22^{\circ} 10^{\prime} 56^{\prime \prime}$, E $114^{\circ} 18^{\prime} 12^{\prime \prime}$, Figure 1) are obtained from the Hong Kong Observatory (HKO), and are assumed to represent the overall wind field over southern waters of Hong Kong including station SM17, SM18 and SM19. The period of 29 years (from1990 to 2018) is divided into six groups with 5 years per group to illustrate the variations in wind speeds and the frequency of wind events in the long term.

\section{Results}

\subsection{Time series of DO at surface and bottom}

The time series of DO during 1990-2018 at SM17, SM18 and SM19 showed that both the surface and bottom DO fluctuated, usually being high in winter and low in summer (Figure 2). In 
summer, the bottom DO was all low in June, July and August, and drops to the hypoxic levels occasionally in August. Hypoxic DO occurred more frequently at SM18 than SM17 and SM19, with 2, 4 and 2 times at SM17, SM18 and SM19, respectively, during 29 years. A hypoxic event has never lasted over 2 months in a year at one station and it does not usually occur at the 3 stations in the same month with the exception in August 2011 when the bottom DO was 0.4 $\mathrm{mg} / \mathrm{L}$ and $0.9 \mathrm{mg} / \mathrm{L}$ at SM18 and SM19, respectively. These indicate that hypoxic events are episodic and have not developed a seasonal phenomenon over a coastal scale covering the 3 stations. Furthermore, the bottom DO does not show any clear decreasing trend over the past decades as the linear regression over time (the red dashed line) is not significant (Figure 2).

\subsection{The relationships between bottom DO, stratification and winds}

In summer, the water column is usually stratified in estuarine and coastal areas due to river outflow and surface heating. In this study, we use the differences in sigma density between surface and bottom layers $(\triangle \sigma)$ to describe the strength of water column stratification. We use the differences in DO between surface and bottom layers $(\triangle \mathrm{DO})$ and Apparent Oxygen Utilization (AOU) to indicate DO consumption due to decomposition of organic matter in the bottom water mass. The correlation analysis (Table 1) shows that bottom DO is correlated to $\triangle \sigma$ at the 3 stations with correlation coefficient, $\mathrm{r}$, being $\sim 0.70$ at $\mathrm{p}<0.01$. The correlation coefficient $\mathrm{r}$ between $\triangle \mathrm{DO}$ and $\Delta \sigma$ is all significant at 3 Stns, reaching 0.8 at SM19. Similarly, AOU is significantly correlated to $\triangle \sigma$ as AOU increases with $\triangle \sigma$ increasing. These relationships indicate that the strength of water column stratification plays a regulating role in the DO variability.

Since it takes some time for DO to be consumed to a low level from the surface DO, wind speeds over 7 days are placed before a bottom DO value in summer during 1990-2018 at 
SM17, SM18 and SM19 (Figure 3) to inspect visually the wind effect on the low bottom DO. Generally, bottom DO is seen to decrease during a period of low wind speeds and is elevated obviously after each episodic high wind period. For example, the bottom DO increased, reaching $7.8 \mathrm{mg} / \mathrm{L}$ and $6.8 \mathrm{mg} / \mathrm{L}$ in June 1990 at SM17 and SM18, respectively, after the daily averaged wind speed blew for 7 days at 14.9, 15.2, 11.5, 8.2, 6.8, 3.8 and $9.6 \mathrm{~m} / \mathrm{s}$. When an event of hypoxia occurs, it is usually after a period of low winds. For example, bottom DO was $0.4 \mathrm{mg} / \mathrm{L}$ and $0.9 \mathrm{mg} / \mathrm{L}$ in August 2011 at SM18 and SM19, respectively, after the daily averaged wind speed blew for 7 days at 4.0, 3.8, 4.4, 3.4, 5.7, 4.5 and $3.6 \mathrm{~m} / \mathrm{s}$. This reflects the close connection between bottom DO and wind speed. The correlation analysis of bottom DO, AOU, $\triangle \mathrm{DO}, \Delta \sigma$ vs. wind speeds for 1-7 preceding days before a low DO event (Table 2) shows that correlation is better between these DO related parameters and 5-7 days averaged wind speed before sampling than 1-3 days averaged wind speed before sampling. We choose $V_{7}$ ( 7 days averaged wind speed before sampling) to represent the preceding wind speed. Bottom DO is positively correlated to wind speeds while $\mathrm{AOU}, \triangle \mathrm{DO}$ and $\Delta \sigma$ are negatively and significantly correlated to wind speeds.

The time series of $\mathrm{V}_{7}$ for DO in summer at SM17, SM18 and SM19 (Figure 4) does not show any decreasing trend during 1990-2018. The relationship between bottom DO, $\triangle \sigma$ and $\mathrm{V}_{7}$ during 1990-2018 at three stations (Figure 5) shows that when the wind speed is higher than 8 $\mathrm{m} / \mathrm{s}, \Delta \sigma$ is almost close to 0 and bottom DO is usually $5-6 \mathrm{mg} / \mathrm{L}$. The frequency of wind speed $\mathrm{V}_{7}$ vs bottom DO during 1990-2018 in summer at SM17, SM18 and SM19 (Table 3(a)) shows that occurrences of bottom DO $<3 \mathrm{mg} / \mathrm{L}$ is 0 when the averaged wind speed in preceding 7 days is $>8 \mathrm{~m} / \mathrm{s}$. 

level occasionally. Since hypoxic events (DO $<2 \mathrm{mg} / \mathrm{L}$ ) occurred rarely in the Pearl River estuarine coastal waters, we take $3 \mathrm{mg} / \mathrm{L}$ as the indicator or an event of low-oxygen water mass

formation. The frequency of the low-oxygen events varies at different wind speeds, being $9.4 \%$, $4.9 \%, 1.7 \%$ and 0 of bottom DO in summer of 29 years for $>5,>6,>7$ and $>8 \mathrm{~m} / \mathrm{s}$ in wind speed, respectively. We consider an event with a probability $<5 \%$ as a small-probability event. When wind speed is $>6 \mathrm{~m} / \mathrm{s}$, the water column can be largely mixed and the probability of bottom hypoxic events have a $<5 \%$ chance to occur. Therefore, wind speeds $>6 \mathrm{~m} / \mathrm{s}$ are strong enough to interrupt the water column stratification. The accumulative frequency of the $\Delta \sigma$-descending group vs the ascending wind speed $\mathrm{V}_{7}$ groups during 1990-2018 in summer (Table 3(b)) shows that occurrences of $\Delta \sigma>15$ and the other 3 groups decrease when the wind speed increases. For example, occurrences of $\triangle \sigma>15$ is 0\% at SM19 and $<5 \%$ at SM17 and SM18 when the averaged wind speed in preceding 7 days is $>6 \mathrm{~m} / \mathrm{s}$.

\subsection{The frequency of wind events}

Winds $>6 \mathrm{~m} / \mathrm{s}$ are found to be a wind event that is strong enough to mix the water column (Figure 5). Wind events were very frequent over southern waters of Hong Kong (Figure 3). The frequency vs. wind speeds in June, July, August and September during 1990-2018 shows that wind speeds are usually between $2 \mathrm{~m} / \mathrm{s}$ and $9 \mathrm{~m} / \mathrm{s}$ and wind speeds $<2 \mathrm{~m} / \mathrm{s}$ or $>9 \mathrm{~m} / \mathrm{s}$ occur rarely (Figure 6). In June and July, wind speeds are mostly $4-7 \mathrm{~m} / \mathrm{s}$ and are reduced to $2-5 \mathrm{~m} / \mathrm{s}$ in August. In September, strong wind speeds occur more frequently than August. The accumulative frequency of wind speeds $>6 \mathrm{~m} / \mathrm{s}$ is $14.3,14.2,10.0$ and 13.0 days per month in June, July, August and September, respectively. Compared to other months, the wind condition is much weaker in August. This means that August is most vulnerable to episodic events of hypoxia. 

29 years (Figure 7). It is more apparent that there appears to be a decrease in wind speeds $\geq 6 \mathrm{~m} / \mathrm{s}$ and an increase in wind speeds $<6 \mathrm{~m} / \mathrm{s}$ in August based on 5 years grouping of wind speeds during 1990-2018 while no major changes in wind speeds are apparent in June, July and September (Figure 8). This suggests that the strong wind events occur less frequently in August than other months during the last 10 years (Figure 6). Among the five groups, the frequency of wind speeds $\geq 6 \mathrm{~m} / \mathrm{s}$ appears to show a decreasing trend, especially in June, July and August. For example, in August, the frequency of wind speeds $\geq 6 \mathrm{~m} / \mathrm{s}$ is $12.6,12.4,8.4,10.6,7$ and 9 days per month during 1990-1994, 1995-1999, 2000-2004, 2005-2009, 2010-2014 and 2015-2018, respectively. In the long period of time, this decreasing trend means that low winds may be more frequent, which potentially results in an increase in the frequency of hypoxia in summer.

\section{Discussion}

There is a lack of a significantly decreasing trend in DO in the southern water of Hong Kong during 1990-2018 with occasional drops below the hypoxic level a few times in summer. Nutrients in the southern waters are non-limiting (EPD Report 2017). However, the drop has not lasted for two consecutive months at one station and has not happened at 2 stations in the same month. This demonstrates that the temporal scale of hypoxia occurring in southern waters of Hong Kong are episodic, not a seasonal phenomenon and the spatial scale is small, not even covering the two stations within $12 \mathrm{~km}$. Yin et al. (2013) proposed the concept of ecosystem buffering capacity against hypoxia, which are determined by a number of drivers and processes (Yin and Harrison 2007, 2008; Harrison et al. 2008; Ho et al. 2008; Yin et al. 2010). Wind events of typhoons have been reported to mix the water column and subsequently increase bottom DO (Paerl et al. 1998, 2001; Yin and Harrison 2007; Zhou et al. 2012, 2014; Ni et al. 
2016). This study gives evidence to testify the hypothesis that frequent strong winds interrupt the stratification and slow down the formation of hypoxia.

\subsection{The formation of low DO water mass}

It is the residence time of the bottom layer and DO consumption rate that determine the formation of hypoxia in the bottom. The former depends on the physical processes of water advection, vertical mixing, and air-sea exchange and the latter photosynthesis, chemolithotrophic production, and respiration in the water column and sediment oxygen demand (Paerl 2006; Chen et al. 2015). When the supply of oxygen is cut off to bottom waters, usually due to stratification of the water column, and consumption of DO through respiration exceeds resupply during a sufficiently long period of time, DO will decrease, reaching the level of hypoxia if organic matter is sufficient (Diaz 2001). In many estuarine and coastal systems, excess nutrients lead to increased primary production, adding new organic matter to the coastal waters. Generally, a coastal water body receiving a large freshwater input with basic features of low physical energy (tidal, currents, or wind) is prone to hypoxia (Diaz 2001).

\subsection{The interruptive role of wind events on hypoxia formation}

Many studies have demonstrated that physical processes such as estuarine circulation, tide and wind determine the residence time of bottom water and play a crucial role in the establishment, maintenance and termination of hypoxia (Simpson et al. 1981, 1990; Yin and Harrison 2007; Rabouille et al. 2008; Wang et al. 2012). Whether an estuary is stratified or mixed depends on the transformation between kinetic energy and potential energy induced by these physical factors (Simpson et al. 1981, 1990). The freshwater from the river flows above the seawater, and hence exerts a buoyancy/stratifying influence in the estuary. The tides affect the water column in two ways: tidal straining and tidal stirring (Simpson et al. 2005). Winds can 
affect the turbulent mixing in several ways, including (1) direct mixing due to shear imposed at the surface by the wind stress, (2) generation of waves and wave breaking, and (3) modification of the plume velocity profile, and shear, through coastal set-up and/or straining of isopycnals (Li et al. 2007; Wilson et al. 2008; Wang et al. 2015; Pan and Gu 2016). Chen et al. (2015) pointed that wind speed and direction are the most important among the physical factors influencing oxygen dynamics in the Yangtze Estuary. A 10\% increase in wind speed reduced the areal extent of hypoxia by $46.66 \%$, and a $10 \%$ reduction increased the hypoxic area by $67.28 \%$ (Chen et al. 2015). A previous study has shown the effect of a typhoon event on interrupting the formation of hypoxia in the Hong Kong waters (Zhou et al. 2012). In the Mississippi River-Northern Gulf of Mexico, the size of the 'dead zone' was found to be strongly correlated with high river discharges and strong stratification (Justic et al. 1996). The Baltic Sea with persistent stratification is prone to the occurrences of hypoxia (Conley et al. 2002; Diaz and Rosenberg 2008; Lehmann et al. 2014). The lack of wind events is a favourable condition for the formation of hypoxia when organic matter supply is sufficient. Our results show that the occurrences of hypoxia are usually after a long period of low winds (Figure 3). The wind speed of $6 \mathrm{~m} / \mathrm{s}$ can be considered as the threshold of a wind event, above which the stratified water column can be mixed to interrupt the formation of the bottom hypoxia in coastal waters south of Hong Kong. The examination of the monthly frequency of such wind events $(>6 \mathrm{~m} / \mathrm{s})$ reveals that wind events $>6 \mathrm{~m} / \mathrm{s}$ occur every two or three days on average during June, July and September, which appears to be frequent enough to raise the bottom DO in southern waters of Hong Kong. The wind speed is the lowest in August, which explains why most hypoxic events at SM17, SM18 and SM19 occurred in August (Figure 2). The formation process of hypoxia is interrupted, reset and starts over again after such a wind event. The consumption of bottom DO to the hypoxic 
level will take some time as the development of phytoplankton blooms and the bacteria degradation of dissolved organic matter require a period of time, saying 7 days at least. Previous study found that phytoplankton in bottled waters took 3-4 days to reach the maximum during the incubation of the estuarine water (Yin et al. 2000, 2008) and similarly, DO consumption in bottled samples of estuarine surface waters takes 3-4 days to consume $5-7 \mathrm{mg} / \mathrm{L}$ to $2 \mathrm{mg} / \mathrm{L}$ during dark closed incubation, but DO consumption in bottled bottom water to $2 \mathrm{mg} / \mathrm{L}$ took longer time (J. Yao unpubl). Each time when the bottom hypoxia is going to be developed, strong winds slow down its formation. A stronger episodic wind event will interrupt its formation completely. The resuming processes may not be a simple recovery as estuarine coastal water masses are highly variable, which influences phytoplankton growth and its organic matter sinking to the bottom water. In addition, the consumption of DO may also be variable. Apparently, each wind event supplies oxygen to bottom layer, which resets the bottom to a higher initial DO value for consumption and hence, leads to longer formation time for the next hypoxia event to occur. This explains why seasonal and coastal scale hypoxic events have rarely occurred in Hong Kong waters despite of the large nutrient inputs.

Due to the southwest monsoon, the Pearl River estuarine freshwater flows across the southern waters of Hong Kong. SM17 is most affected by the river outflow. SM18 is located in the southern end of Lamma Channel. In the northern end of it, the sewage effluent outfalls of the biggest sewage treatment plant (Stonecutter's CEPT Plant) in Hong Kong are laid in the bottom. Part of the treated effluent flows through the Lamma Channel to the southern waters. Thus, SM18 is most influenced by the sewage effluent. The shallow depth of $12 \mathrm{~m}$ at SM17 makes wind mixing more effective at SM17. SM19 appears to be least influenced by the estuarine 
plume and sewage effluent, and by a wind event due to its deepest depth $(24 \mathrm{~m})$. This explains low occurrences of hypoxia at SM19 at wind speeds $>5 \mathrm{~m} / \mathrm{s}$ (Table 3 ).

\subsection{Ecosystem buffering capacity}

Cloern (2001) pointed out that some coastal ecosystems can accommodate an excess nutrient enrichment without showing apparent eutrophication symptoms. Yin et al. (2013) proposed that it is the ecosystem buffering that makes the Pearl River estuary "robust" to $\mathrm{N}$ enrichment. It is determined by physical driving forces such as monsoons, river outflow, tidal cycles and rainfall, and some of them become dominant over different temporal and spatial scales, which induce circulation, stratification and turbulent mixing. As a result, the fields of light, salinity, temperature and nutrients vary, thus influencing algal growth and DO consumption. When anthropogenic nutrients enter coastal waters, there would be a series of physical and biological processes before nutrient enrichment causes any ecological impacts. If the ecosystem buffering capacity is large enough, the input may not lead to any impacts. Inversely, algae bloom and hypoxia may occur.

Lacking of a seasonal hypoxia over the coastal scale in the Pearl River estuarine influenced waters suggests that the ecosystem buffering capacity plays a regulating role in controlling the production and accumulation of algal blooms and DO consumption and potential occurrence of hypoxia (Lee et al. 2006; Harrison et al. 2008). In addition to these physical controls on hypoxia, the low PO4 concentrations relative to nitrogen $(\mathrm{N}: \mathrm{P} \sim 100: 1)$ may limit the phytoplankton biomass production through $\mathrm{P}$ limitation and hence the amount of organic matter sinking to depth (Yin et al. 2004). Zooplankton grazing pressure could also be an influencing factor in limiting the phytoplankton biomass via the top down control in HK waters in summer (Ho et al. 2008). Strong solar radiation can reach the shallow bottom layer of HK waters 
(although it might still be limiting) and support some growth of phytoplankton at depth that can release and partially replenish DO (Ho et al. 2008). In summary, hypoxia might therefore develop only when bottom DO consumption exceeds the buffering capacity maintained by all these physical and biochemical factors above.

The frequency of wind events $(>6 \mathrm{~m} / \mathrm{s})$ appears to show a decreasing trend in summer in the long term, which may be well related to global climate change. Climate change is likely contributing to the increase in dead zones, by influencing factors such as winds, precipitation and temperature (Altieri and Gedan 2015). For example, changes in the direction and strength of seasonal wind patterns can modify hypoxic conditions by affecting circulation patterns that determine nutrient delivery and water column stratification (Conley et al. 2007; Altieri and Gedan 2015). Changes in rainfall patterns can increase discharges of freshwater and nutrients to coastal ecosystems (Diaz and Rosenberg 2008). Recently, global warming is predicted to enhance stratification, decrease oxygen solubility and accelerate respiration, thus exacerbating the oxygen depletion in nutrient-enriched coastal systems (Breitburg et al. 2018). If the weak wind condition or the tendency of decreasing wind speeds continues in the future, the occurrence of hypoxia in this system may become more frequent, and likely develops into large areas of seasonal hypoxia. This may contribute to a relatively large hypoxic zone in the south water of Macau reported recently (Su et al. 2017; Lu et al. 2018; Qian et al. 2018). This raises an alarming signal and an urgent need to fully understand the influence of climate change and how multiple factors interact to drive the dead zone dynamics.

\section{Conclusions}

Due to population growth and economic development in last 60 years, riverine nutrients have increased dramatically, which leads to increased organic matter production in estuarine and 
coastal waters. However, not all estuaries or coastal waters show eutrophication symptoms such as red tides or hypoxia (Cloern 2001). Nutrients in the Pearl River have been steadily increasing in the last 4 decades, but hypoxic water mass has not developed into a seasonal phenomenon in a large scale over the plume influenced waters in the Northern South China Sea. Our study testified the hypothesis that frequent strong wind events destroy the water column stratification and interrupt the formation of hypoxia. The wind speed $>6 \mathrm{~m} / \mathrm{s}$ can be considered to be the threshold of an interruptive wind event in Hong Kong waters. Our finding demonstrates the role winds play in the ecosystem buffering capacity against enrichment of nutrients. The finding is significant because climate change may have resulted in the decreasing trend in the frequency of wind speeds $>6 \mathrm{~m} / \mathrm{s}$ in the recent years, which is an alarming signal for more occurrences of hypoxic events in the region. The water quality management needs to keep long-term monitoring and develop strategies for controlling and regulating the input of nutrients in coastal waters to the level that is below the threshold for triggering the hypoxia in the downstream of the estuary. 


\section{References}

Altieri, A. H., and Gedan K. B.: Climate change and dead zones. GCB Bioenergy. 21(4): 13951406. https://doi.org/10.1111/gcb.12754, 2015.

Bianchi, T. S., Dimarco S. F., Cowan J. H., Hetland R. D., Chapman P., Day J. W., and Allison M. A.: The science of hypoxia in the northern gulf of Mexico: a review. Sci. Total Environ. 408(7): 1471-1484. https://doi.org/10.1016/j.scitotenv.2009.11.047, 2010.

Breitburg, D., Levin L. A., Oschlies, A., Gregoire, M., Chavez, F. P., Conley, D. J., Garcon, V., et al.: Declining oxygen in the global ocean and coastal waters. Science. 359(6371): 46. https://doi.org/10.1126/science.aam7240, 2018.

Capet, A., Beckers J. M., and Grégoire M.: Drivers, mechanisms and long-term variability of seasonal hypoxia on the Black Sea Northwestern Shelf \& Ndash; is there any recovery after eutrophication?. Biogeosciences. 10(6): 3943-3962. https://doi.org/10.5194/bg-10-3943$2013,2013$.

Chen, X., Shen Z., Li Y., and Yang Y.: Physical controls of hypoxia in waters adjacent to the Yangtze estuary: a numerical modeling study. Mar. Pollut. Bull. 97(1-2): 349-364. https://doi.org/10.1016/j.marpolbul.2015.05.067, 2015.

Cloern, J. E.: Our evolving conceptual model of the coastal eutrophication problem. Mar. Ecol. Prog. Ser. 210: 223-253. https://doi.org/10.3354/meps210223, 2001.

Conley, D. J., Humborg C., Rahm L., Savchuk O. P., and Wulff F.: Hypoxia in the baltic sea and basin-scale changes in phosphorus biogeochemistry. Environ. Sci. Technol. 36(24): 53155320. https://doi.org/10.1021/es025763w, 2002. 
Conley, D. J., Carstensen J., Aertebjerg G., Christensen P. B., Dalsgaard T., Hansen J. L. S., and Josefson A. B.: Long-term changes and impacts of hypoxia in Danish coastal waters. Ecological Applications, 17(sp5): S165-S184. https://doi.org/10.1890/05-0766.1, 2007.

Diaz, R. J.: Overview of hypoxia around the world. J. Environ. Qual. 30(2): 275-281. https://doi.org/10.2134/jeq2001.302275x, 2001.

Diaz, R. J., and Rosenberg R.: Spreading dead zones and consequences for marine ecosystems. Science, 321(5891): 926-929. https://doi.org/10.1126/science.1156401, 2008.

Du, J., Shen J., Park K., Wang Y. P., and Yu X.: Worsened physical condition due to climate change contributes to the increasing hypoxia in Chesapeake Bay. Sci. Total Environ. 630: 707-717. https://doi.org/10.1016/j.scitotenv.2018.02.265, 2018.

Harrison, P. J., Yin K., Lee J. H. W., Gan J., and Liu H.: Physical-biological coupling in the Pearl River Estuary. Cont. Shelf Res. 28(12): 1405-1415. https://doi.org/10.1016/j.csr.2007.02.011, 2008.

Ho, A. Y. T., Xu J., Yin K., Yuan X., He L., Jiang Y., Lee J. H. W., Anderson D. M., Harrison P. J.: Seasonal and spatial dynamics of nutrients and phytoplankton biomass in Victoria Harbour and its vicinity before and after sewage abatement. Mar. Pollut. Bull. 57(6-12): 313-324. https://doi.org/10.1016/j.marpolbul.2008.04.035, 2008.

$\mathrm{Hu}$, J., and Li S.: Modeling the mass fluxes and transformations of nutrients in the Pearl River Delta, China. Journal of Marine Systems, 78(1): 146-167. https://doi.org/10.1016/j.jmarsys.2009.05.001, 2009.

Justić, D., Rabalais N. N., and Turner R. E.: Effects of climate change on hypoxia in coastal waters: a doubled $\mathrm{CO}_{2}$ scenario for the Northern Gulf of Mexico. Limnol. Oceanogr. 41(5): 992-1003. https://doi.org/10.4319/lo.1996.41.5.0992, 1996. 
Lee, J. H. W., Harrison P. J., Kuang C., and Yin K.: Eutrophication dynamics in Hong Kong coastal waters: physical and biological interactions. The environment in Asian Pacific Harbors. Springer, Netherlands, 187-206. https://doi.org/10.1007/1-4020-3655-8_13, 2006.

Lehmann, A., Hinrichsen H. H., Getzlaff K., and Myrberg K.: Quantifying the heterogeneity of hypoxic and anoxic areas in the Baltic Sea by a simplified coupled hydrodynamic-oxygen consumption model approach. Journal of Marine Systems. 134(6): 20-28. https://doi.org/ 10.1016/j.jmarsys.2014.02.012, 2014.

Li, D., Zhang J., Huang D., Wu Y., and Liang J.: Oxygen depletion off the Changjiang (Yangtze River) Estuary. Science in China, 45(12): 1137-1146. https://doi.org/10.3969/j.issn.16747313.2002.12.008, 2002.

Li, M., Zhong L., Boicourt W. C., Zhang S., and Zhang D. L.: Hurricane-induced destratification and restratification in a partially-mixed estuary. J. Mar. Res. 65(65): 169-192(24). https://doi.org/10.1357/002224007780882550, 2007.

Li, X., Lu C., Zhang Y., Zhao H., Wang J., Liu H., Yin K.: Low dissolved oxygen in the Pearl River estuary in summer: Long-term spatio-temporal patterns, trends, and regulating factors. Mar. Pollut. Bull. https://doi.org/10.1016/j.marpolbul.2019.110814, 2019.

Lu, Z., Gan J., Dai M., Liu H., and Zhao X.: Joint effects of extrinsic biophysical fluxes and intrinsic hydrodynamics on the formation of hypoxia west off the Pearl River Estuary. J. Geophys. Res.: Oceans. 123(9). https://doi.org/10.1029/2018JC014199, 2018.

Monitoring Group, Water Policy and Planning Group, Environmental Protection Department, Hong Kong Special Administrative Region. Marine Water Quality in Hong Kong in 2017, 2017. 
Ni, X., Huang D., Zeng D., Zhang T., Li H., and Chen J.: The impact of wind mixing on the variation of bottom dissolved oxygen off the Changiiang Estuary during summer. Journal of Marine Systems. 154: 122-130. https://doi.org/10.1016/j.jmarsys.2014.11.010, 2016.

Paerl, H. W.: Assessing and managing nutrient-enhanced eutrophication in estuarine and coastal waters: interactive effects of human and climatic perturbations. Ecol. Eng. 26(1): 40-54. https://doi.org/10.1016/j.ecoleng.2005.09.006, 2006.

Paerl, H. W., Pinckney J. L., Fear J. M., and Peierls B. L.: Ecosystem responses to internal and watershed organic matter loading: consequences for hypoxia in the eutrophying Neuse River Estuary, North Carolina, USA. Mar. Ecol. Prog. Ser. 166(8): 17-25. https://doi.org/10.3354/meps166017, 1998.

Paerl H. W., Bales J. D., Ausley L. W.: Ecosystem impacts of three sequential hurricanes (Dennis, Floyd, and Irene) on the United States' largest lagoonal estuary, Pamlico Sound, NC. Proceedings of the National Academy of Sciences of the United States of America, 98(10): 5655-5660, 2001.

Pan, J., and Gu Y.: Cruise observation and numerical modeling of turbulent mixing in the Pearl River Estuary in summer. Cont. Shelf Res. 120: 122-138. https://doi.org/10.1016/j.csr.2016.03.019, 2016.

Qian, W., and Gan J., Liu J., He B., and Dai M.: Current status of emerging hypoxia in a eutrophic estuary: The lower reach of the Pearl River Estuary, China. Estuarine Coastal Shelf Sci. 205: 58-67. https://doi.org/10.1016/j.ecss.2018.03.004, 2018.

Rabalais, N. N., Turner R. E., Justić D.: Charaterization of hypoxia: Topic 1 Report for the Integrated Assessment of Hypoxia in the Gulf of Mexico. NOAA Coastal Ocean Program. Decision Analysis Series No.15, 167pp, 1998. 
Rabalais, N. N., Turner R. E., and Wiseman W. J.: Gulf of Mexico hypoxia, a.k.a. ।"the dead zonel". Annu. Rev. Ecol. Syst. 33: 235-263. https://doi.org/10.2307/3069262, 2002.

Rabalais, N. N., Díaz R. J., Levin L. A., Turner R. E., and Zhang J.: Dynamics and distribution of natural and human-caused hypoxia. Biogeosciences. 7(2): 585-619. https://doi.org/10.5194/bgd-6-9359-2009, 2010.

Rabouille, C., Conley D. J., Dai M., Cai W., and Mckee B.: Comparison of hypoxia among four river-dominated ocean margins: the Changjiang (Yangtze), Mississippi, Pearl, and Rhône rivers. Cont. Shelf Res. 28(12): 1527-1537. https://doi.org/10.1016/j.csr.2008.01.020, 2008.

Scully, M. E.: Wind modulation of dissolved oxygen in Chesapeake Bay. Estuaries Coasts. 33(5): 1164-1175, https://doi.org/10.1007/s12237-010-9319-9, 2010.

Scully, M. E.: Physical controls on hypoxia in Chesapeake Bay: a numerical modeling study. J. Geophys. Res.: Oceans. 118(3): 1239-1256. https://doi.org/10.1002/jgrc.20138, 2013.

Simpson, J. H., and Bowers D. B.: Models of stratification and frontal movement in shelf seas. Deep-Sea Res., Part A. 28(7): 727-738. https://doi.org/10.1016/0198-0149(81)90132-1, 1981.

Simpson, J. H., Brown J., Matthews J., and Allen G.: Tidal straining, density currents, and stirring in the control of estuarine stratification. Estuaries. 13(2): 125-132. https://doi.org/ $10.2307 / 1351581,1990$.

Simpson, J. H., Williams E., Brasseur L. H., and Brubaker J. M.: The impact of tidal straining on the cycle of turbulence in a partially stratified estuary. Cont. Shelf Res. 25(1): 51-64. https://doi.org/10.1016/j.csr.2004.08.003, 2005.

Su, J., Dai M., He B., Wang L., Gan J., Guo X., Zhao H., and Yu F.: Tracing the origin of the oxygen-consuming organic matter in the hypoxic zone in a large eutrophic estuary: the 
lower reach of the Pearl River Estuary, China. Biogeosciences Discussions, 14(18): 1-24. https://doi.org/10.5194/bg-2017-43, 2017.

Väli, G., Meier H.E.M., and Elken J.: Simulated halocline variability in the Baltic Sea and its impact on hypoxia during 1961-2007. J. Geophys. Res.: Oceans. 118(12): 6982-7000. https://doi.org/10.1002/2013JC009192, 2013.

Wang, H., Dai M., Liu J., Kao S., Zhang C., Cai W., Wang G., et al.: Eutrophication-driven hypoxia in the East China Sea off the Changiiang Estuary. Environ. Sci. Technol. 50: 22552263. https://doi.org/10.1021/acs.est.5b06211, 2016.

Wang, J. F., Macdonald D. G., Orton P. M., Cole K., and Lan J.: The effect of discharge, tides, and wind on lift-off turbulence. Estuaries Coasts, 38(6): 2117-2131. https://doi.org/10.1007/s12237-015-9958-y, 2015.

Wang, B., Wei Q., Chen J., and Xie L.: Annual cycle of hypoxia off the changjiang (yangtze river) estuary. Mar. Environ. Res. 77: 1-5. https://doi.org/10.1016/j.marenvres.2011.12.007, 2012.

Wei, X., Zhan H., Ni P., and Cai S.: A model study of the effects of river discharges and winds on hypoxia in summer in the Pearl River Estuary. Mar. Pollut. Bull. 113(1-2): 414-427. https://doi.org/10.1016/j.marpolbul.2016.10.042, 2016.

Wilson, R. E., Swanson R. L., and Crowley H. A.: Perspectives on long-term variations in hypoxic conditions in western long island sound. J. Geophys. Res. 113(C12): C12011. https://doi.org/10.1029/2007jc004693, 2008.

Xu, J., Yin K., Liu H., Lee J. H. W., Anderson D. M., Ho A. Y. T., and Harrison P. J.: A comparison of eutrophication impacts in two harbours in Hong Kong with different 
hydrodynamics. Journal of Marine Systems, 83(3-4): 276-286. https://doi.org/ 10.1016/j.jmarsys.2010.04.002, 2010.

Ye, F., Huang X., Shi Z., and Liu Q.: Distribution Characteristics of Dissolved Oxygen and Its Affecting Factors in the Pearl River Estuary During the Summer of the Extremely Drought Hydrological Year 2011. China Environ. Sci. 34(5): 1707-1714, 2013.

Yin, K., and Harrison P. J.: Influence of the Pearl River estuary and vertical mixing in Victoria Harbor on water quality in relation to eutrophication impacts in Hong Kong waters. Mar. Pollut. Bull. 54(6): 646-656. https://doi.org/10.1016/j.marpolbul.2007.03.001, 2007.

Yin, K., and Harrison P. J.: Nitrogen over enrichment in subtropical Pearl River estuarine coastal waters: possible causes and consequences. Cont. Shelf Res. 28(12): 1435-1442. https://doi.org/10.1016/j.csr.2007.07.010, 2008.

Yin, K., Qian P., Chen J. C., Hsieh P. H. D., and Harrison P. J.: Dynamics of nutrients and phytoplankton biomass in the Pearl River estuary and adjacent waters of Hong Kong during summer: preliminary evidence for phosphorus and silicon limitation. Mar. Ecol. Prog. 194(3): 295-305. https://doi.org/10.3354/meps194295, 2000.

Yin, K., Lin Z., and Ke Z.: Temporal and spatial distribution of dissolved oxygen in the Pearl River estuary and adjacent coastal waters. Cont. Shelf Res. 24(16): 1935-1948. https://doi.org/10.1016/j.csr.2004.06.017, 2004.

Yin, K., Xu J., and Harrison P.J.: A Comparison of eutrophication processes in three Chinese subtropical semi-enclosed embayments with different buffering capacities. Coastal Lagoons: Critical Habitats of Environmental Change, 372-398. https://doi.org/ 10.1201/EBK1420088304-c15, 2010. 
Zhou, W., Yin K., Harrison P. J., and Lee J. H. W.: The influence of late summer typhoons and high river discharge on water quality in Hong Kong waters. Estuarine Coastal Shelf Sci. 111(4): 35-47. https://doi.org/10.1016/j.ecss.2012.06.004, 2012.

Zhou, W., Yuan X., Long A., Huang H., and Yue W.: Different hydrodynamic processes regulated on water quality (nutrients, dissolved oxygen, and phytoplankton biomass) in three contrasting waters of Hong Kong. Environ. Monit. Assess. 186(3): 1705-1718. https://doi.org/10.1007/s10661-013-3487-6, 2014.

Zhu, Z., Zhang J., Wu Y., Zhang Y., Lin J., and Liu S. M.: Hypoxia off the Changjiang (Yangtze River) Estuary: oxygen depletion and organic matter decomposition. Mar. Chem. 125(1-4): 108-116. https://doi.org/10.1016/j.marchem.2011.03.005, 2011.

Zhu, J., Zhu Z., Lin J., Wu H., and Zhang J.: Distribution of hypoxia and pycnocline off the Changjiang Estuary, China. Journal of Marine Systems, 154(Part A): 28-40. https://doi.org/ 10.1016/j.jmarsys.2015.05.002, 2016.

\section{Acknowledgments}

This study is part of NSFC-GD Joint Scheme Project (U1701247), SML99147-42080013, NSFC grant (91328203) and NMEMC Key Laboratory for Ecological Environment in Coastal Area (Grant 201819). We acknowledge the Hong Kong EPD and HKO for permitting us to use their water quality monitoring data and weather data for this study. H. Liu acknowledge the support of Hong Kong Research Grants Council (T21/602/16 and N_HKUST609/15).

\section{Data availability}

The wind speeds data used in this manuscript is open to the public and can be downloaded from HKO website. The time series of water quality monitoring data is provided by Hong Kong EPD and will be available after this manuscript is published. 


\section{Author contribution}

The contributions made by each of the authors are as follows. Juan Yao analyses the long time series data and writes the original manuscript. Juying Wang and Hongbin Liu review the manuscript and give valuable and helpful comments. Kedong Yin provides guidance on the conceptualization of the scientific story and makes revision of the manuscript.

\section{Competing interests}

The authors declare no conflict of interest.

\section{Figure legends}

Figure 1. Map of the Pearl River estuary and Hong Kong waters and Waglan Island showing the selected EPD water quality monitoring stations.

Figure 2. The time series of surface and bottom DO during 1990-2018 at SM17, SM18 and SM19 (the red dashed line indicates that the linear regression is not significant).

Figure 3(a). Time series of wind speed and bottom DO during 1990-2004 in summer at SM17, SM18 and SM19 (the red dashed line denotes the level of DO=2 mg/L).

Figure 3(b). Time series of wind speed and bottom DO during 2005-2018 in summer at SM17, SM18 and SM19 (the red dashed line denotes the level of DO=2 mg/L).

Figure 4. Time series of averaged wind speed $V_{7}$ before sampling during 1990-2018 in summer at SM17, SM18 and SM19. There is no significant trend by linear regression.

Figure 5. The relationship between bottom DO, $\triangle \sigma$ and $V_{7}$ during 1990-2018 at SM17, SM18 and SM19.

Figure 6. The frequency of grouped wind speeds during 1990-2018 in summer (left panel) and accumulative frequency of grouped wind speeds (accumulated from the largest wind speed group to the smallest one) (right panel). 
https://doi.org/10.5194/bg-2020-188

Preprint. Discussion started: 8 June 2020

(c) Author(s) 2020. CC BY 4.0 License.

(c) (1)

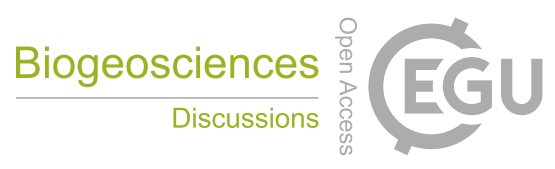

534 Figure 7. The monthly averages of wind speeds for June, July, August and September,

535

536

537 respectively, over 29 years (the red and blue solid lines denote the significant regression).

Figure 8. The averaged monthly frequency of wind speeds $<6$ and $\geq 6 \mathrm{~m} / \mathrm{s}$ at Waglan Island in summer (the red dashed line denotes the frequency of wind speeds $\geq 6 \mathrm{~m} / \mathrm{s}$ over 29 years). 
https://doi.org/10.5194/bg-2020-188

Preprint. Discussion started: 8 June 2020

(C) Author(s) 2020. CC BY 4.0 License.

Table 1. The Correlation Coefficient, $r$, between bottom DO, AOU, $\triangle \mathrm{DO}$ and $\triangle \sigma$.

\begin{tabular}{|c|c|c|c|}
\hline Variables & SM17 (n=287) & SM18 $(n=292)$ & SM19 $(n=292)$ \\
\hline DO vs. $\Delta \sigma$ & $-0.71^{* * *}$ & $-0.69^{* *}$ & $-0.68 * *$ \\
\hline AOU vs. $\triangle \sigma$ & $0.69^{* * *}$ & $0.67^{* * *}$ & $0.67^{* * *}$ \\
\hline$\triangle \mathrm{DO}$ vs. $\triangle \sigma$ & $0.75^{* *}$ & $0.77^{\text {** }}$ & $0.80^{* *}$ \\
\hline
\end{tabular}


https://doi.org/10.5194/bg-2020-188

Preprint. Discussion started: 8 June 2020

(C) Author(s) 2020. CC BY 4.0 License.

540 Table 2. The Correlation Coefficient, $r$, between bottom DO, AOU, $\triangle \mathrm{DO}, \triangle \sigma$ and wind speed in summer.

\begin{tabular}{|c|c|c|c|c|c|c|c|c|c|c|c|c|}
\hline & \multicolumn{4}{|c|}{ SM17 (n=94) } & \multicolumn{4}{|c|}{ SM18 (n=97) } & \multicolumn{4}{|c|}{ SM19 (n=97) } \\
\hline & $\mathrm{DO}$ & $\mathrm{AOU}$ & $\triangle \mathrm{DO}$ & $\Delta \sigma$ & DO & $\mathrm{AOU}$ & $\triangle \mathrm{DO}$ & $\Delta \sigma$ & DO & $\mathrm{AOU}$ & $\triangle \mathrm{DO}$ & $\Delta \sigma$ \\
\hline $\mathrm{V}_{7}$ & $\underline{0.23}^{*}$ & $-0.23^{*}$ & $-0.27^{* * *}$ & 0.07 & $\underline{0.47^{* *}}$ & $-0.49^{* *}$ & $-0.36^{* *}$ & -0.14 & $0.46^{* *}$ & $-0.48^{* *}$ & $-0.36^{* *}$ & -0.19 \\
\hline $\mathrm{V}_{6}$ & $\underline{0.23}^{*}$ & $\underline{-0.24^{*}}$ & $-0.33^{* *}$ & 0.001 & $\underline{0.47}^{* *}$ & $\underline{-0.49}^{* *}$ & $-0.40^{* *}$ & -0.17 & $0.47^{* *}$ & $-0.49^{* *}$ & $-0.40^{* *}$ & $-0.23^{*}$ \\
\hline $\mathrm{V}_{5}$ & $\underline{0.23}^{*}$ & $-0.23^{*}$ & $\underline{-0.36}^{* *}$ & -0.08 & $0.46^{* *}$ & $-0.48^{* *}$ & $\underline{-0.43}^{* * *}$ & $-0.21^{*}$ & $\underline{0.48}^{* *}$ & $\underline{-0.50}^{* *}$ & $-0.47^{* * *}$ & $-0.26^{*}$ \\
\hline $\mathrm{V}_{4}$ & 0.20 & $-0.21^{*}$ & $-0.33^{* *}$ & -0.15 & $0.43^{* *}$ & $-0.46^{* *}$ & ${\underline{-0.43^{* *}}}^{* *}$ & $-0.21^{*}$ & $\underline{0.48}^{* *}$ & $\underline{-0.50}^{* *}$ & $\underline{-0.49}^{* *}$ & $-0.23^{*}$ \\
\hline $\mathrm{V}_{3}$ & 0.18 & -0.19 & $-0.27^{* *}$ & -0.19 & $0.41^{* *}$ & $-0.43^{* *}$ & $-0.40^{* *}$ & $-0.21^{*}$ & $0.41^{* *}$ & $-0.44^{* *}$ & $-0.44^{* *}$ & $-0.22^{*}$ \\
\hline $\mathrm{V}_{2}$ & 0.13 & -0.14 & -0.20 & -0.17 & $0.32^{* *}$ & $-0.34^{* *}$ & $-0.32^{* *}$ & -0.18 & $0.28^{* *}$ & $-0.31^{* *}$ & $-0.35^{* *}$ & -0.17 \\
\hline $\mathrm{V}_{1}$ & 0.09 & -0.11 & -0.15 & -0.16 & 0.16 & -0.18 & -0.16 & -0.09 & 0.09 & -0.12 & $-0.21^{*}$ & -0.08 \\
\hline
\end{tabular}


https://doi.org/10.5194/bg-2020-188

Preprint. Discussion started: 8 June 2020

(C) Author(s) 2020. CC BY 4.0 License.

543 Table 3(a). The Frequency (\%) of bottom DO at different $\mathrm{V}_{7}$ Wind Speeds during 1990-2018 in summer.

\begin{tabular}{lccccc}
\hline & $(\mathrm{mg} / \mathrm{L})$ & $\geq 5 \mathrm{~m} / \mathrm{s}$ & $\geq 6 \mathrm{~m} / \mathrm{s}$ & $\geq 7 \mathrm{~m} / \mathrm{s}$ & $\geq 8 \mathrm{~m} / \mathrm{s}$ \\
& $3<\mathrm{DO} \leq 4$ & 16.0 & 7.5 & 4.3 & 1.1 \\
SM17 & $2<\mathrm{DO} \leq 3$ & 8.5 & 5.3 & 1.1 & 0.0 \\
& $\mathrm{DO} \leq 2$ & 2.1 & 0.0 & 0.0 & 0.0 \\
\hline SM18 & $3<\mathrm{DO} \leq 4$ & 13.4 & 8.3 & 2.1 & 0.0 \\
& $2<\mathrm{DO} \leq 3$ & 10.3 & 5.2 & 3.1 & 0.0 \\
\hline SM19 & $\mathrm{DO} \leq 2$ & 2.1 & 1.0 & 0.0 & 0.0 \\
& $3<\mathrm{DO} \leq 4$ & 21.7 & 11.3 & 3.1 & 0.0 \\
& $2<\mathrm{DO} \leq 3$ & 4.1 & 2.1 & 0.0 & 0.0 \\
\hline Average & $\mathrm{DO} \leq 2$ & 1.0 & 1.0 & 1.0 & 0.0 \\
\hline
\end{tabular}


https://doi.org/10.5194/bg-2020-188

Preprint. Discussion started: 8 June 2020

(C) Author(s) 2020. CC BY 4.0 License.

544 Table 3(b). The Accumulative Frequency (\%) of $\triangle \sigma$ in the 4 descending groups vs 4 ascending groupings of

$545 \mathrm{~V}_{7}$ Wind Speeds during 1990-2018 in summer (June-August). Group $\geqslant 5 \mathrm{~m} / \mathrm{s}$ includes the other 3 groups,

546 group $\geqslant 6 \mathrm{~m} / \mathrm{s}$ includes the other 2 groups and so on.

\begin{tabular}{|c|c|c|c|c|c|}
\hline & $\left(\mathrm{kg} / \mathrm{m}^{3}\right)$ & $\geq 5 \mathrm{~m} / \mathrm{s}$ & $\geq 6 \mathrm{~m} / \mathrm{s}$ & $\geq 7 \mathrm{~m} / \mathrm{s}$ & $\geq 8 \mathrm{~m} / \mathrm{s}$ \\
\hline \multirow{4}{*}{ SM17 } & $\triangle \sigma>15$ & 3.2 & 3.2 & 0.0 & 0.0 \\
\hline & $10<\triangle \sigma \leq 15$ & 14.9 & 10.6 & 6.4 & 1.1 \\
\hline & $5<\Delta \sigma \leq 10$ & 29.8 & 18.1 & 7.4 & 5.3 \\
\hline & $\triangle \sigma \leq 5$ & 25.5 & 16.0 & 9.6 & 4.3 \\
\hline \multirow{5}{*}{ SM18 } & $\Delta \sigma>15$ & 4.1 & 4.1 & 2.1 & 1.0 \\
\hline & $10<\triangle \sigma \leq 15$ & 13.4 & 9.3 & 4.1 & 1.0 \\
\hline & $5<\Delta \sigma \leq 10$ & 17.5 & 10.3 & 5.2 & 2.1 \\
\hline & $\triangle \sigma \leq 5$ & 24.7 & 16.5 & 13.4 & 5.2 \\
\hline & $\triangle \sigma>15$ & 1.0 & 0.0 & 0.0 & 0.0 \\
\hline \multirow[t]{3}{*}{ SM19 } & $10<\Delta \sigma \leq 15$ & 12.4 & 11.3 & 3.1 & 1.0 \\
\hline & $5<\triangle \sigma \leq 10$ & 18.6 & 9.3 & 4.1 & 0.0 \\
\hline & $\triangle \sigma \leq 5$ & 33.0 & 23.7 & 17.5 & 8.2 \\
\hline
\end{tabular}


https://doi.org/10.5194/bg-2020-188

Preprint. Discussion started: 8 June 2020

(c) Author(s) 2020. CC BY 4.0 License.

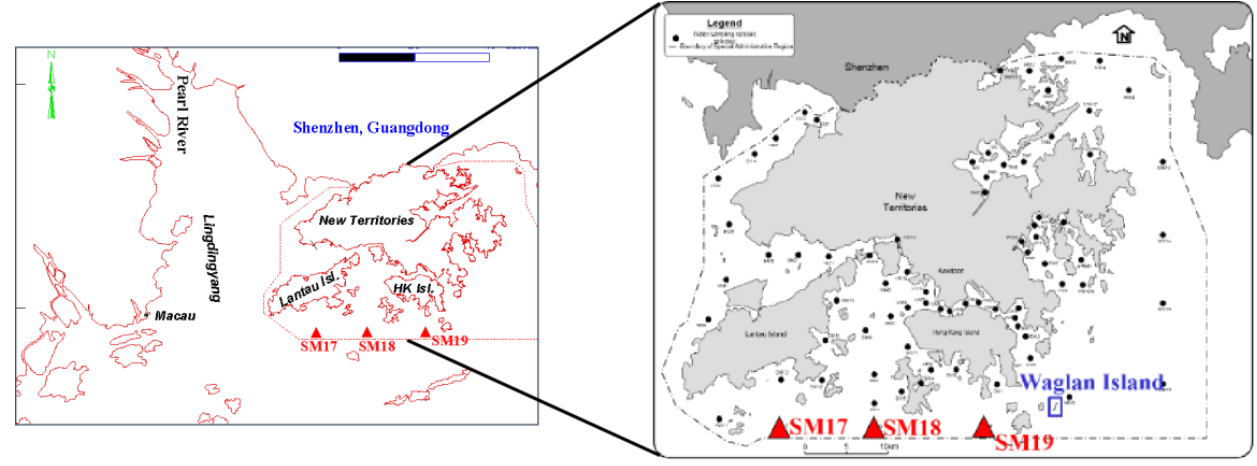

Figure 1. Map of the Pearl River estuary and Hong Kong waters and Waglan Island showing the selected EPD water quality monitoring stations.

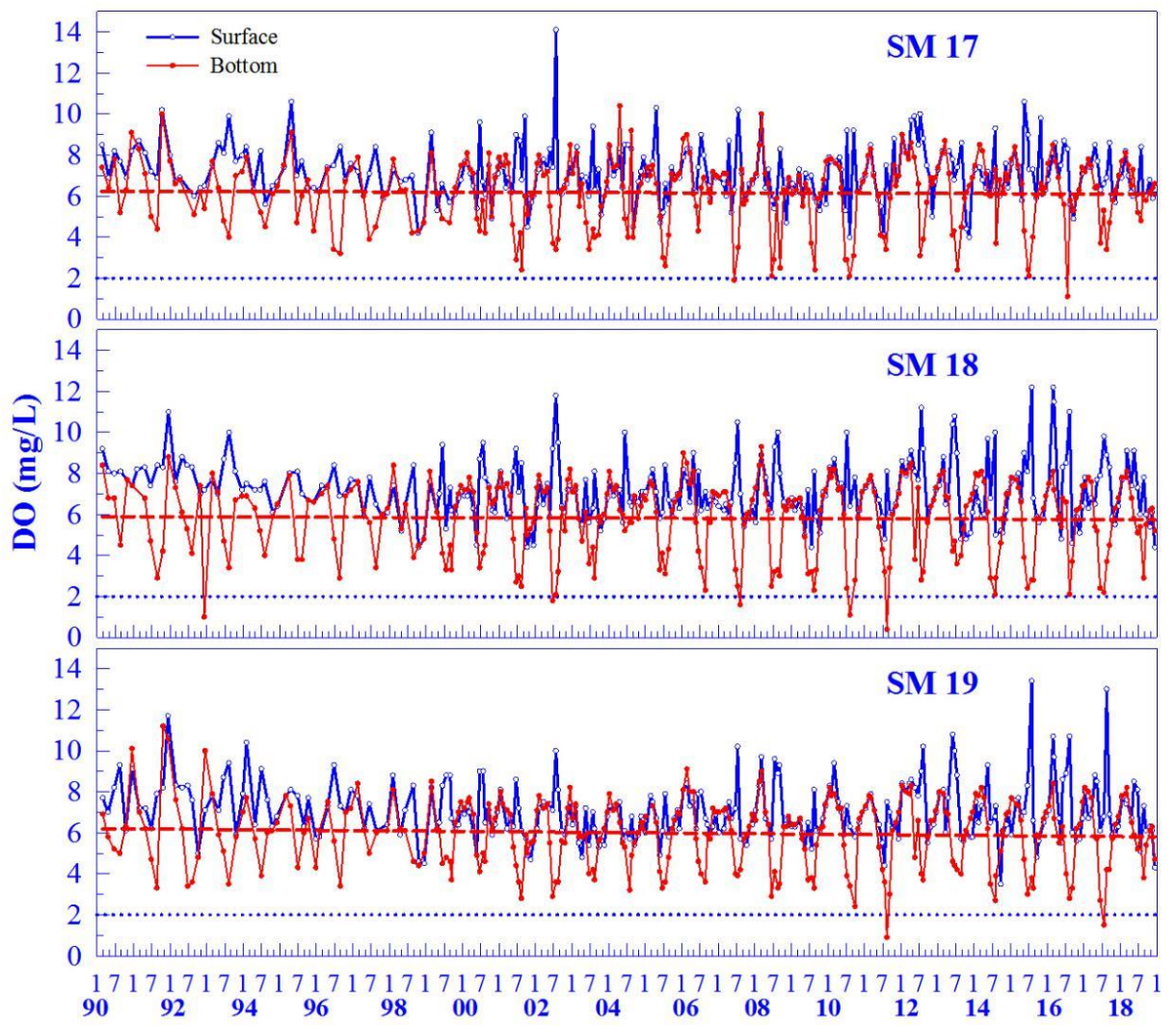

Figure 2. The time series of surface and bottom DO during 1990-2018 at SM17, SM18 and SM19 (the red dashed line indicates that the linear regression is not significant). 
https://doi.org/10.5194/bg-2020-188

Preprint. Discussion started: 8 June 2020

(c) Author(s) 2020. CC BY 4.0 License.

(a)
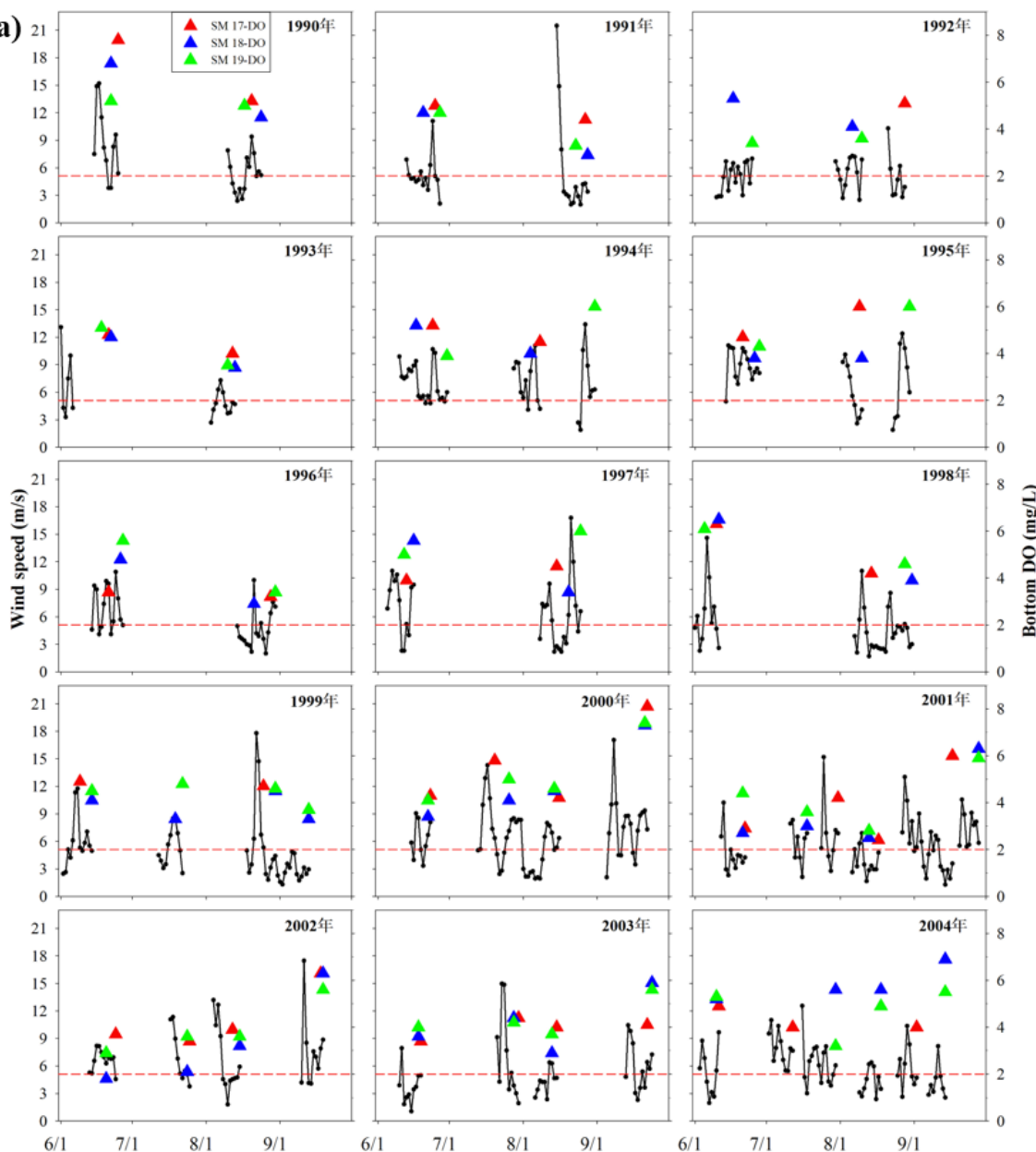

Figure 3(a). Time series of wind speed and bottom DO during 1990-2004 in summer at SM17, SM18 and SM19 (the red dashed line denotes the level of $\mathrm{DO}=2 \mathrm{mg} / \mathrm{L}$ ). 
https://doi.org/10.5194/bg-2020-188

Preprint. Discussion started: 8 June 2020

(c) Author(s) 2020. CC BY 4.0 License.

(b)
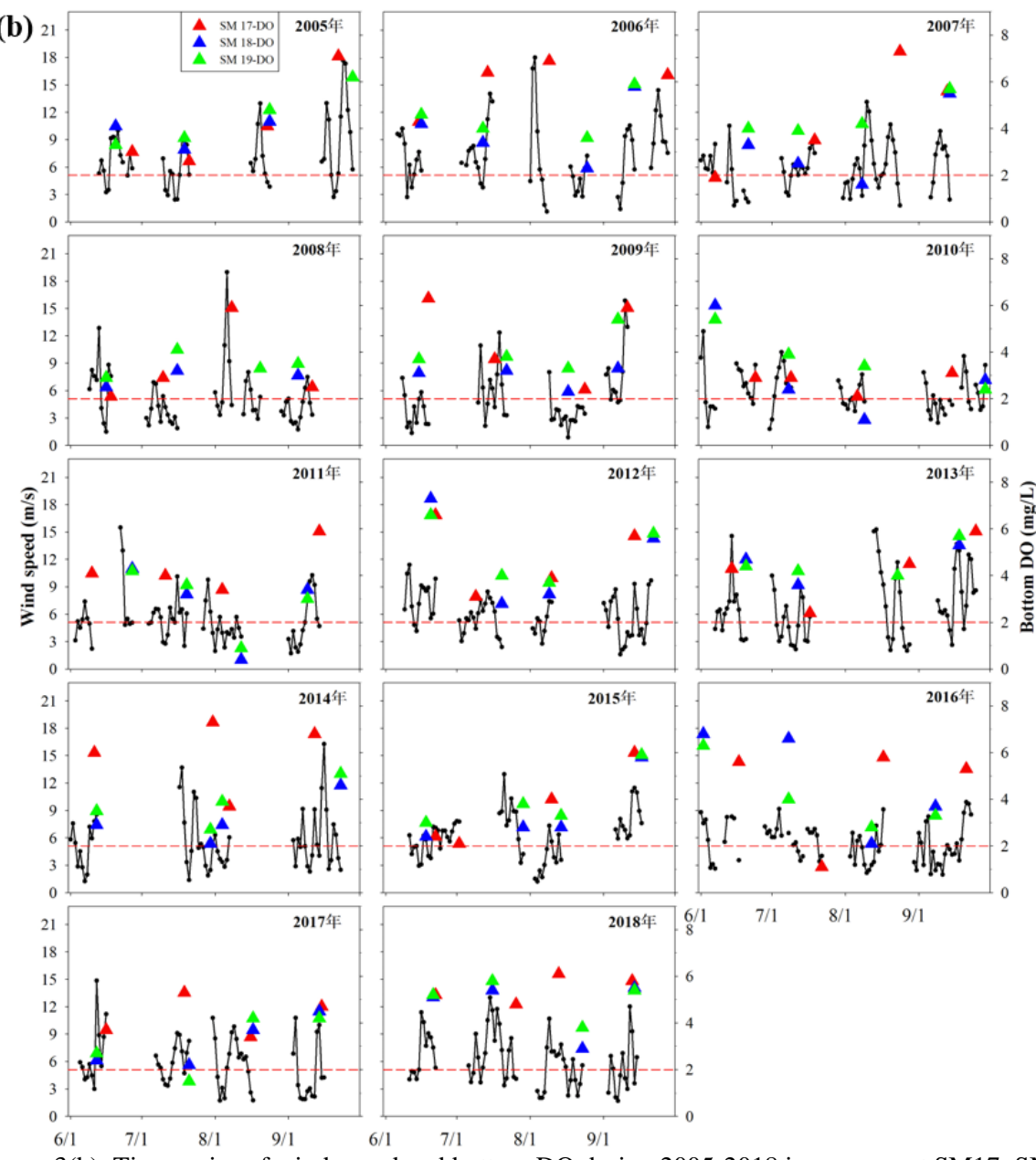

Figure 3(b). Time series of wind speed and bottom DO during 2005-2018 in summer at SM17, SM18 and SM19 (the
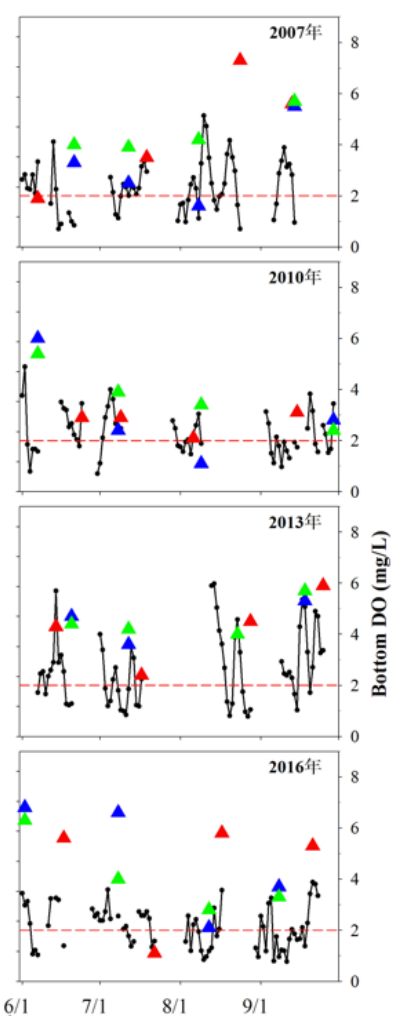
https://doi.org/10.5194/bg-2020-188

Preprint. Discussion started: 8 June 2020

(c) Author(s) 2020. CC BY 4.0 License.
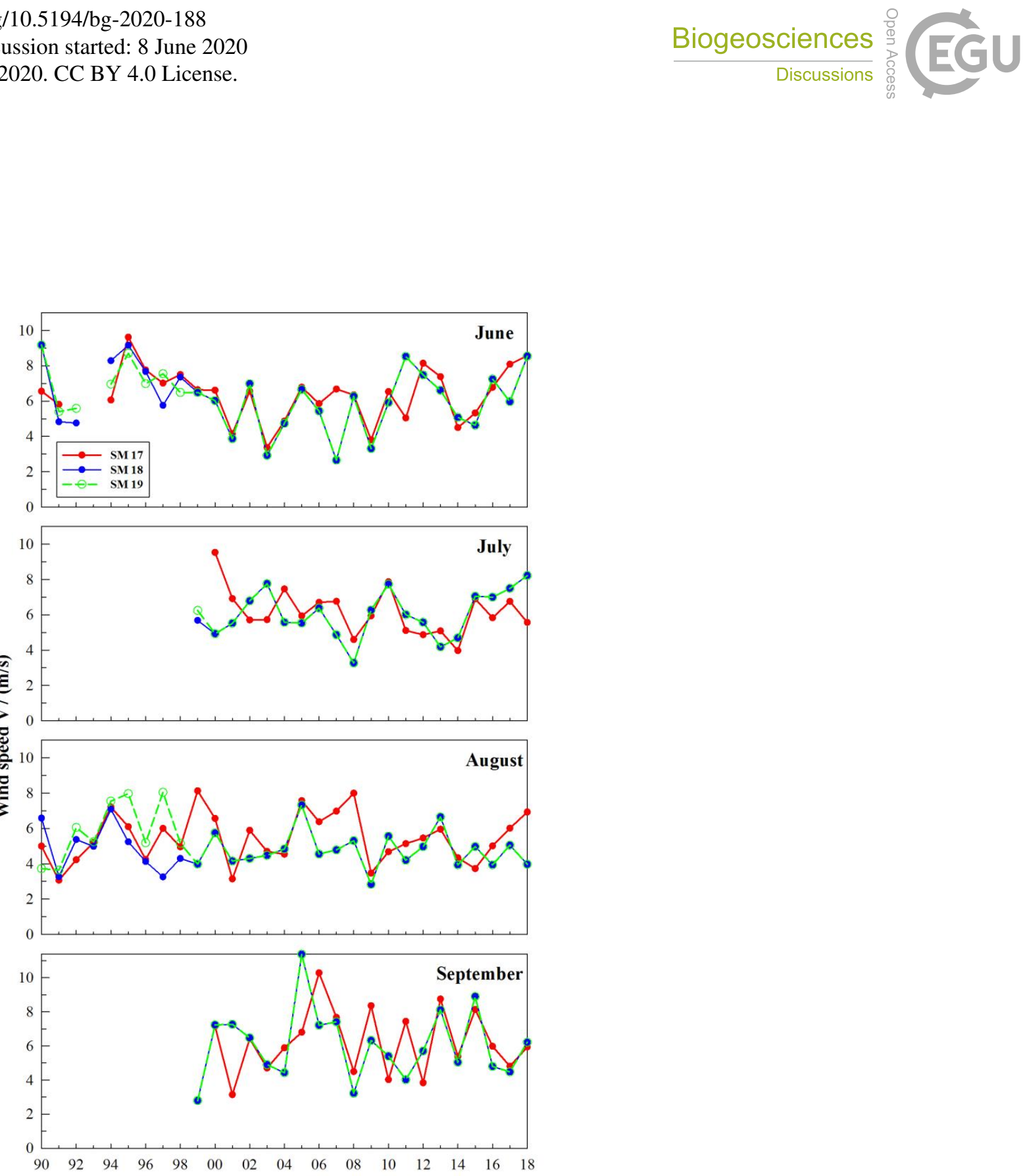

Figure 4. Time series of averaged wind speed $V_{7}$ before sampling during 1990-2018 in summer at SM17, SM18 and SM19. There is no significant trend by linear regression. 
https://doi.org/10.5194/bg-2020-188

Preprint. Discussion started: 8 June 2020

(c) Author(s) 2020. CC BY 4.0 License.

(c) (i)
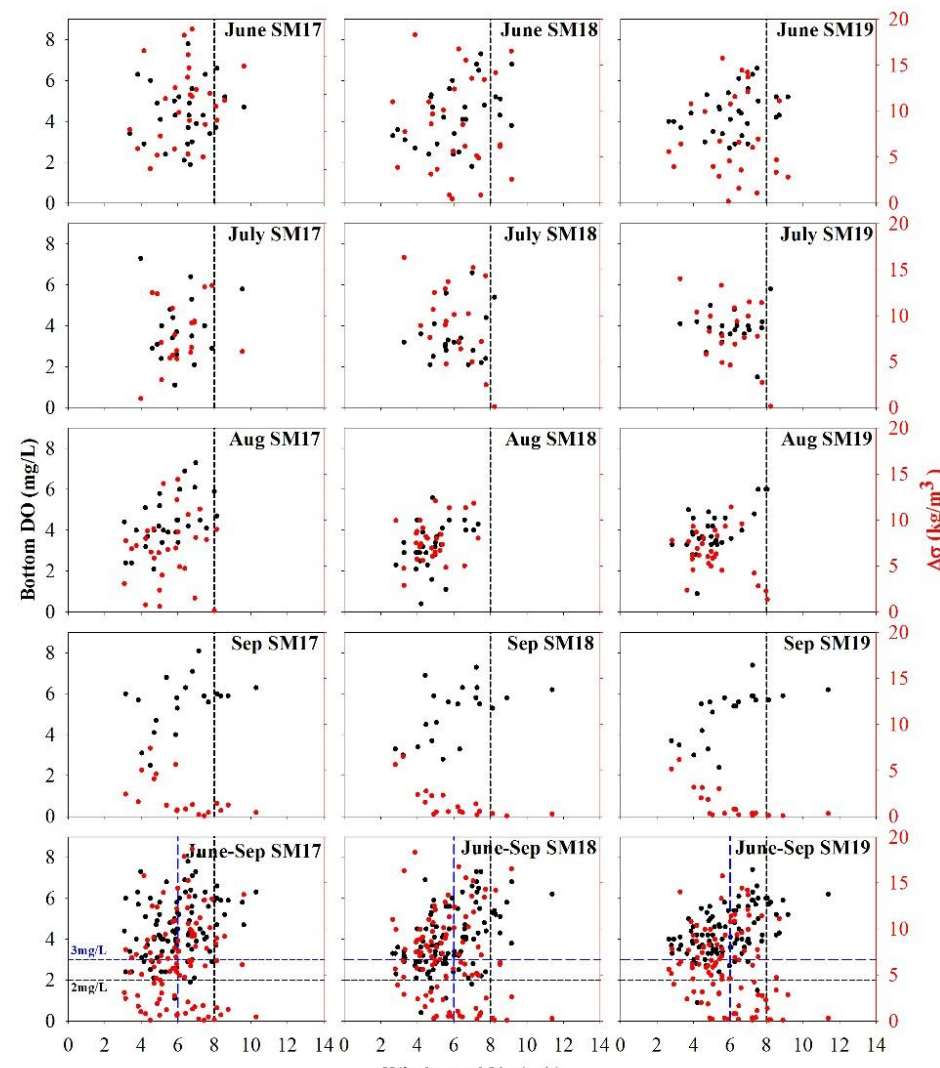

Figure 5. The relationship between bottom DO, $\triangle \sigma$ and $V_{7}$ during 1990-2018 at SM17, SM18 and SM19. 

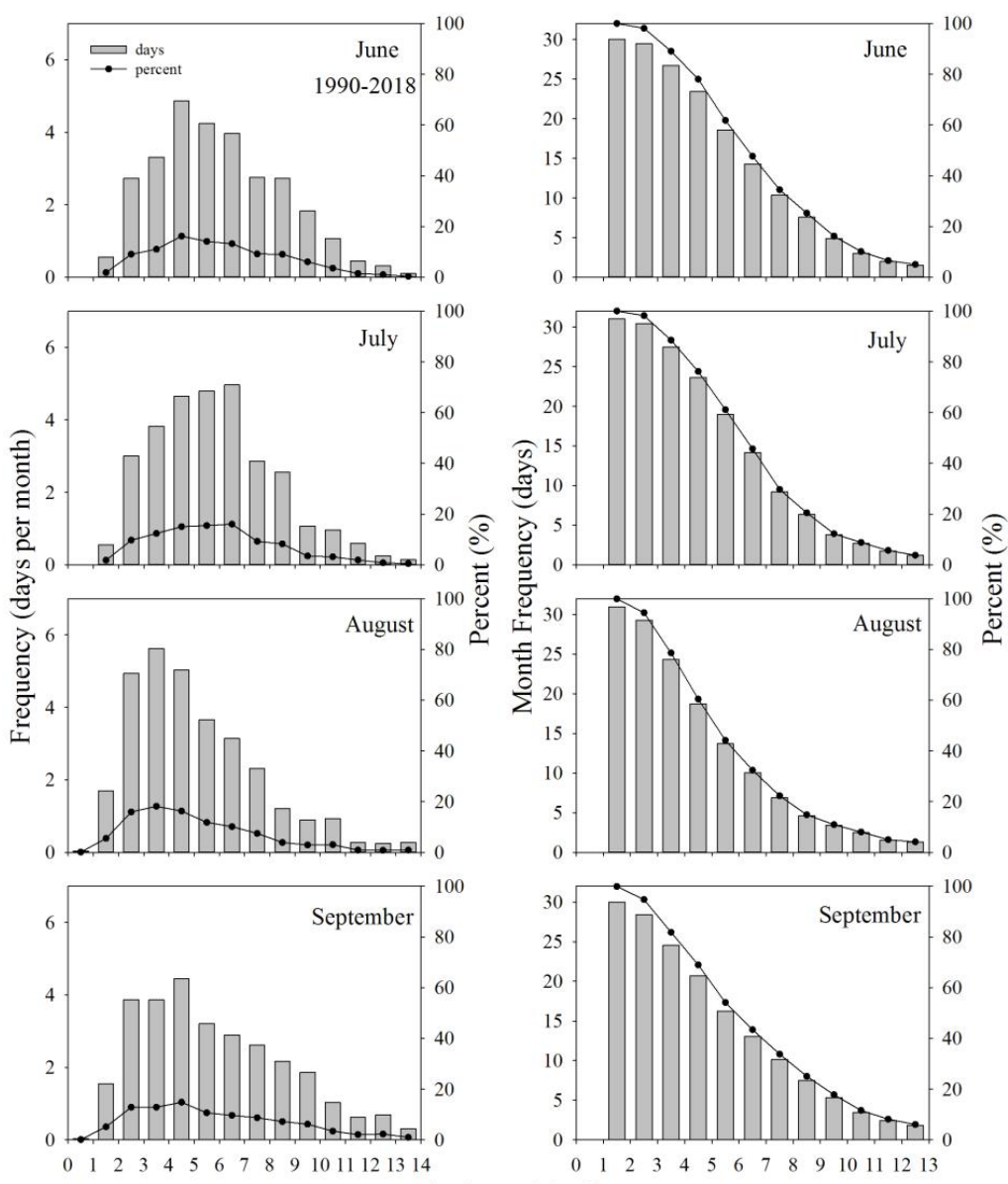

566 Figure 6. The frequency of grouped wind speeds during 1990-2018 in summer (left panel) and accumulative

567 frequency of grouped wind speeds (accumulated from the largest wind speed group to the smallest one) (right panel) 
https://doi.org/10.5194/bg-2020-188

Preprint. Discussion started: 8 June 2020

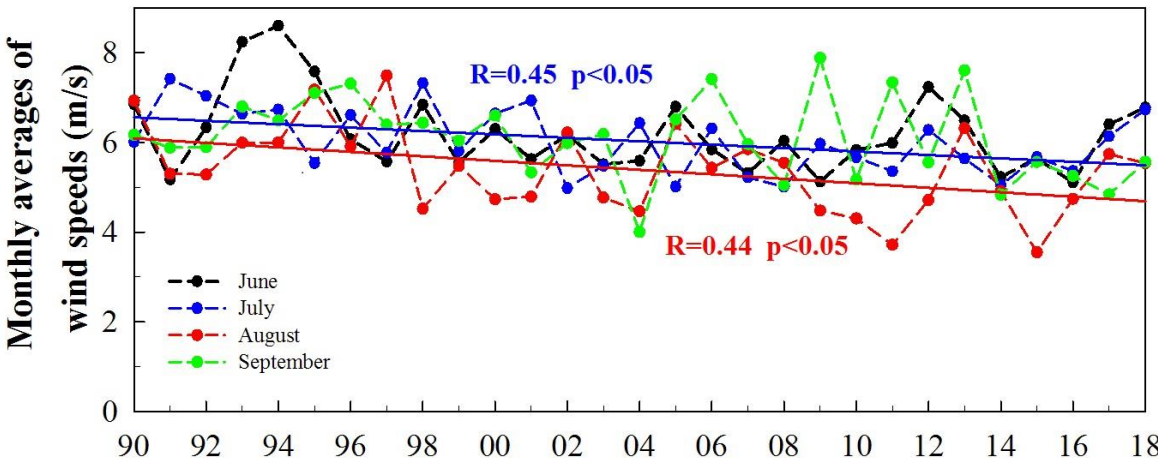

Figure 7. The monthly averages of wind speeds for June, July, August and September, respectively, over 29 years

(the red and blue solid lines denote the significant regression).

571
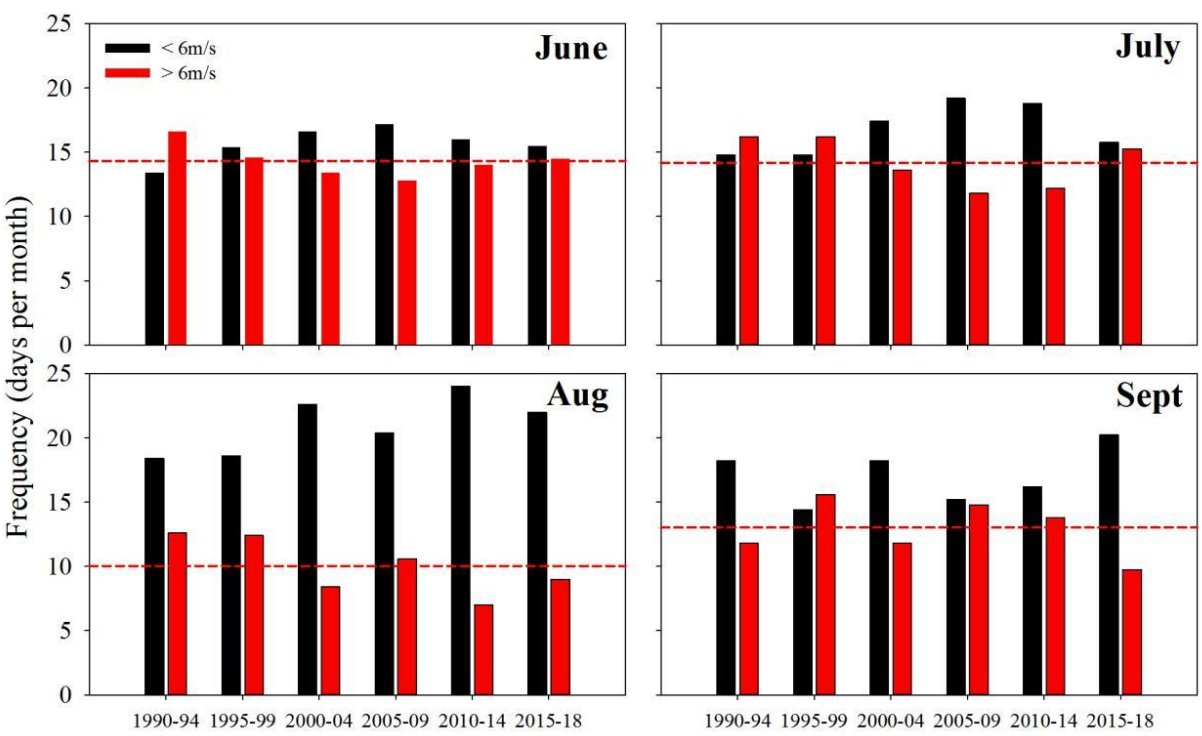

Figure 8 . The averaged monthly frequency of wind speeds $<6$ and $\geq 6 \mathrm{~m} / \mathrm{s}$ at Waglan Island in summer (the red

dashed line denotes the frequency of wind speeds $\geq 6 \mathrm{~m} / \mathrm{s}$ over 29 years). 